\title{
Pengaruh Pembelajaran Saintifik Think Pair Share (S-TPS) Terhadap Minat Belajar Siswa Kelas 5 SD
}

\author{
*Oktaviastuti Awalia Fajrin'1, Naniek Sulistya Wardani ${ }^{2}$, Tego Prasetyo ${ }^{3}$
}

${ }^{123}$ Pendidikan Guru Sekolah Dasar, Universitas Kristen Satya Wacana, Kota Salatiga, Indonesia

A R T I C L E I N F O

Article history:

Received 10 November 2018

Received in revised form 09 December 2018

Accepted 15 January 2019

Available online 25

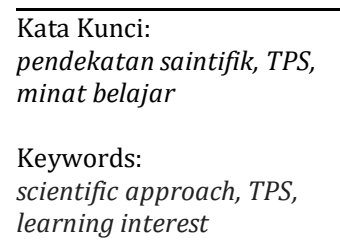

February 2019

\begin{abstract}
A B S T R A K
Rendahnya minat belajar siswa dengan menggunakan model pembelajaran konfensional. Tujuan dari penelitian ini adalah untuk mengetahui pengaruh pembelajaran Saintifik Think Pair Share (S-TPS) terhadap minat belajar siswa kelas 5 SD. Jenis penelitian ini adalah penelitian eksperimen dengan dengan desain quasi experiment research. Teknik pengambilan sampel adalah purposive stratified quota sampling. Sampel yang digunakan adalah siswa kelas 5A SDN Cebongan 02 sebanyak 22 siswa sebagai kelas kontrol, dan siswa kelas 5B SDN Cebongan 02 sebanyak 24 siswa sebagai kelas eksperimen. Teknik pengumpulan data non tes menggunakan instrumen berupa angket yang berisi 20 pernyataan. Teknik analisis data adalah uji t, dengan syarat uji $t$ adalah normalitas data pada kelas eksperimen dan kelas kontrol. Normalitas kelas eksperimen dengan Df. 24 dan Sig. $0,251>0,05$, maka kelas eksperimen berdistribusi normal. Kelas kontrol dengan Df. 22 dan Sig. $106>0,05$, maka kelas kontrol berdistribusi
\end{abstract} normal. Homogenitas kedua kelas dengan Sig. 0,781 >0,05, maka kedua kelas homogen. Uji $t$ dengan hasil Sig. (2-tailed) 0,021 <0,05, maka terdapat pengaruh yang signifikan pembelajaran STPS terhadap minat belajar siswa kelas 5 SD, dan hasil t-hitung 2,399 > 2,067 t-tabel, maka terdapat perbedaan pembelajaran S-TPS terhadap minat belajar siswa kelas 5 SD.

\begin{abstract}
A B S T R A C T
The purpose of this study was to determine the effect of scientific learning Think Pair Share (S-TPS) on the learning interest of 5th grade students. This type of research is an experimental study with a quasi experiment research design. The sampling technique was purposive stratified quota sampling. The sample used was grade 5A students at Cebongan 02 Elementary School as many as 22 students as a control class, and 5B grade students at Cebongan 02 Elementary School as many as 24 students as the experimental class. The non-test data collection technique uses an instrument in the form of a questionnaire containing 20 statements. The data analysis technique is the test, with the condition of the $t$ test is the normality of the data in the experimental class and the control class. The normality of the experimental class with Df. 24 and Sig. 0.251>0.05, then the experimental class is normally distributed. Control class with Df. 22 and Sig. 106>0.05, then the control class is normally distributed. Homogeneity of both classes with Sig. $0.781>0.05$, then both classes are homogeneous. $T$ test with the results of Sig. (2-tailed) $0.021<0.05$, then there is a significant effect of S-TPS learning on the learning interest of 5 th grade students, and the results of $t$-count $2.399>2.067 t$-table, then there are differences in S-TPS learning towards interest in learning 5th grade elementary school students.
\end{abstract}

\section{Pendahuluan}

Pendidikan menjadi salah satu alternatif yang tepat untuk mengubah kehidupan seseorang. Melalui pendidikan seseorang mampu mendapatkan pembelajaran tentang bagaimana belajar, meningkatkan prestasi, bersosialisasi, dan menjadi seseorang yang berbudi pekerti. Permendikbud No. 22 Tahun 2016 tentang Standar Proses menekankan bahwa pembelajaran tematik terpadu menuntut siswa lebih aktif mengembangkan potensi dirinya, sehingga diperlukan model pembelajaran yang tepat dan sesuai dengan karakteristik siswa. Keaktifan siswa ketika pembelajaran dapat dilihat jika siswa memiliki minat belajar 
yang tinggi(Kemendikbud, 2003). Pendidikan merupakan suatu proses yang mencakup tigadimensi, individu, masyarakat atau komunitas nasional dari individu tersebut, dan seluruh kandungan realitas, baik material maupun spiritualang memainkan peranan dalam menentukan sifat, nasib, bentuk manusia maupun masyarakat (Nurkholis, 2013). Lembaga pendidikan mengemban amanah untuk menyiapkan peserta didik agar mampu bertahan hidup dan membentuk karakter yang sesuai dengan nilai-nilai yang berlaku secara lokal, nasional, dan global atau humanisasi (Tilaar dalam Musanna, 2017).

(Djamarah, 2010) mengungkapkan bahwa minat adalah kecenderungan yang menetap untuk memperhatikan beberapa aktivitas. Seseorang yang memiliki minat terhadap suatu aktivitas akan memperhatikan aktivitas itu secara konsisten dengan rasa senang. Hal yang sama juga diungkapkan oleh (Djaali, 2012) minat dapat diekspresikan melalui pernyataan yang menunjukkan bahwa siswa lebih menyukai suatu hal daripada lainnya, dapat pula melalui partisipasi dalam suatu aktivitas. Sependapat dengan Djamarah dan Djaali, menurut (Slameto, 2013) minat adalah suatu rasa lebih suka dan rasa ketertarikan pada suatu hal atau aktivitas, tanpa ada yang menyuruh. Kajian dari beberapa definisi para ahli tentang minat, bahwa minat adalah rasa suka dan ketertarikan untuk memperhatikan dan berpartisipasi dalam suatu aktivitas tanpa ada yang menyuruh. Matlin berpendapat bahwa belajar adalah suatu perubahan tingkah laku yang relatif permanen sebagai hasil dari pengalaman. Selanjutnya dalam konteks sekolah, belajar adalah suatu proses usaha yang dilakukan siswa untuk memperoleh suatu perubahan tingkah laku secara keseluruhan, sebagai hasil pengalaman siswa sendiri dalam interaksi dengan lingkungannya (Akbar \& Hawadi, 2004). Secara umum dapat didefenisikan bahwa hasil belajar merupakan penilaian diri siswa (Young, M. E., Klemz, B. R., \& Murphy, 2003), dan perubahan yang dapat diamati, dibuktikan, dan terukur dalam kemampuan atau prestasi yang dialami oleh siswa sebagai hasil dari pengalaman belajar (Nemeth, J., \& Long, 2012). Proits mengungkapkan bahwa hasil belajar dapat menggambarkan kemampuan siswa setelah apa yang mereka ketahui dan pelajari (Molstad, C. E., \& Karseth, 2016). Selanjutnya Robert Gagne berpendapat bahwa hasil belajar siswa terbagi menjadi lima kategori yaitu informasi verbal, keterampilan intelektual,keterampilan motorik, sikap dan strategi kognitif (Djiwandono, 2002).

Berdasarkan pengertian tentang minat belajar terdapat 4 aspek penting yaitu perasaan senang, ketertarikan siswa, perhatian siswa dan keterlibatan siswa. Perasaan senang dapat dilihat ketika siswa memiliki rasa senang ketika mengikuti materi pembelajaran dan senang belajar bersama dengan teman; ketertarikan siswa dapat dilihat ketika siswa mengikuti pembelajaran dengan penuh semangat dan merespon pertanyaan dari guru; perhatian siswa dapat dilihat ketika siswa menyimak materi, menanya materi dan ketika berdiskusi dengan pasangan; sedangkan keterlibatan dapat dilihat ketika siswa mempresentasikan hasil diskusi, mengungkapkan gagasan saat beridiskusi dan menyelesaikan seluruh tugas yang diberikan guru.

Pemilihan pendekatan dan model pembelajaran yang inovatif sangat dibutuhkan untuk meningkatkan minat belajar siswa terutama pada pembelajaran tematik terpadu. Namun, fenomena yang ada kebanyakan guru masih menggunakan model pembelajaran konvensional. (Abdul Majid dan Chaerul Rochman, 2014) memaparkan bahwa model pembelajaran konvensional merupakan model pembelajaran dalam konteks klasikal yang biasa dilakukan dan pembelajaran berpusat pada guru, sehingga dalam pelaksanaannya kurang memperhatikan keseluruhan situasi belajar (belajar non tuntas). Pembelajaran dengan menggunakan model konvensional kurang dapat meningkatkan minat belajar siswa karena siswa kurang berperan aktif ketika mengikuti pembelajaran dan lebih berpusat pada guru. Dari permasalahan di atas, maka rumusan masalah dalam penelitian ini adalah apakah terdapat pengaruh pembelajaran saintifik Think Pair Share (S-TPS) terhadap minat belajar tematik siswa kelas 5 SDN Cebongan 02 Salatiga. Tujuan dari penelitian ini adalah untuk mengetahui pengaruh pembelajaran S-TPS terhadap minat belajar siswa kelas 5 SD.

(Kurniasih, Imas, 2014) menyatakan bahwa pendekatan saintifik adalah pembelajaran yang memberikan kesempatan siswa untuk aktif dalam membangun suatu konsep, hukum atau prinsip dengan melibatkan keterampilan proses dalam kegiatan pembelajaran. Hal yang sama juga diungkapkan (Mulyasa, 2014) menyatakan bahwa pendekatan yang diunggulkan adalah pendekatan saintifik (saintific approach). Pembelajaran dengan pendekatan saintifik menekankan keterlibatan peserta didik dalam berbagai kegiatan yang memungkinkan peserta didik aktif dalam proses mengamati, menanya, mencoba, menalar, mengomunikasikan, dan membangun jejaring. Dari pengertian pendekatan saintifik yang telah dipaparkan oleh pakar di atas, dapat disimpulkan bahwa pendekatan saintifik adalah proses pembelajaran yang melibatkan peserta didik untuk aktif membangun konsep, hukum, atau prinsip dalam proses mengamati, menanya, mencoba, menalar, mengomunikasikan, dan membangun jejaring.

(Wardani, Mardiyana, \& Subanti, 2016), model pembelajaran TPS adalah model pembelajaran yang melibatkan siswa untuk berfikir, berdiskusi dengan pasangannya dan hasil dari diskusi kemudian di sharing kan pada teman-teman di kelas. (Trianto, 2013) TPS merupakan model yang menempatkan siswa 
untuk berfikir, berpasangan, dan berbagi. Gunter (dalam Mutatik, 2018) model pembelajaran TPS adalah pembelajaran dengan cara siswa saling belajar satu sama lain dan mendapatkan jalan keluar dari ide mereka setelah berdiskusi dan membuat ide mereka untuk didiskusikan dalam seluruh kelas. Dengan demikian, pengertian model pembelajaran TPS adalah pembelajaran yang melibatkan siswa untuk berfikir sendiri terlebih dahulu, kemudian berfikir bersama dengan pasangannya, dan hasil disampaikan kepada seluruh siswa di kelas.

Pembelajaran dengan desain sainitifik Think Pair Share (S-TPS) didefinisikan bahwa proses pembelajaran yang memberikan kesempatan kepada peserta didik secara aktif membangun konsep, hukum dan prinsip dengan berpikir sendiri, berdiskusi dengan pasangannya dan hasil diskusi dikomunikasikan kepada teman di kelasnya. Langkah-langkah pendekatan saintifik menurut Hosnan (2014), Imas dan Berlin (2014: 26) dan Daryanto (2014) sebagai berikut: 1) Mengamati, 2) Menanya, 3) Menalar, 4) Mengumpulkan informasi, 5) Mengasosiasikan, 6) Menarik kesimpulan, 7) Mengkomunikasikan, dan 8) Membentuk jejaring. Langkah-langkah model pembelajaran TPS menurut Wardani, Naniek S. (2016:81), Aqib Zainal (2013:24), dan Setiawan, Susanti, \& Mulyani (2013) sebagai berikut: 1) Menyimak kompetensi yang akan dicapai dalam pembelajaran, 2) Menyimak materi pembelajaran yang disampaikan, 3) Berfikir (Think) tentang materi atau permasalahan yang diajukan guru, 4) Duduk berpasangan (Pairs) untuk berdiskusi dengan teman sebelahnya untuk menyelesaikan tugas yang diberikan guru, 5) Diskusi secara pleno, setiap pasangan melaporkan hasil diskusi dan pasangan yang lain memberikan tanggapan terhadap pasangan yang sedang melaporkan hasil diskusinya. (Share), 6) Penegasan materi dengan bimbingan dari guru, 7) Menyimak kesimpulan hasil diskusi, dan 8) Menutup pembelajaran.

Dengan demikian langkah-langkah pembelajaran S-TPS adalah, 1) Menyimak kompetensi yang akan dicapai, 2) Menyimak materi, 3) Menanya tentang permasalahan, 4) Berpikir (Think) secara nalar untuk memecahkan permasalahan, 5) Duduk berpasangan dengan teman sebangku (Pairs) untuk mendiskusikan pemecahan permasalahan, 6) Mengumpulkan informasi yang terkait dengan pemecahan masalah, 7) Mengasosiasikan atau mengolah informasi yang diperoleh untuk memecahkan permasalahan yang disampaikan guru, 8) Sharing tentang permasalahan yang dirumuskan, 9) Menyimak penegasan permasalahan dan kesimpulan, dan 10) Membentuk jejaring.Dalam pembelajaran S-TPS, minat belajar diukur dengan menggunakan instrumen angket minat belajar. Indikator yang digunakan untuk mengukur minat belajar adalah 1) Perasaan senang, 2) Ketertarikan siswa, 2) Keterlibatan siswa, dan 4) Perhatian siswa.

Pembelajaran dengan metode konvensional yang dilaksanakan oleh guru masih kurang memperhatikan ketercapaian kompetensi peserta didik. Guru masih dominan dalam pembelajaran sehingga membuat siswa menjadi pasif. Siswa tidak mengalami pengalaman belajar sendiri untuk mendapatkan pengalaman baru dalam kegiatan belajar mengajar di sekolah, akibatnya minat belajar siswa rendah. Untuk mengatai permasalahan diatas, guru mencoba menerapkan suatu pembelajaran dengan menggunakan S-TPS. Penggunaan pembelajaran S-TPS diharapkan dapat membantu siswa untuk meningktkan minat belajar. S-TPS juga mendorong siswa untuk dapat mengungkapkan dan menyampaikan pendapat yang dimilikinya mengenai pelajaran yang telah dipelajari. Keberhasilan peningkatan minat belajar siswa diukur melalui 1) Menyimak bacaan peristiwa Proklamasi, 2) Mengikuti pembelajaran peristiwa Proklamasi dengan perasaan senang, 3) Mengerjakan latihan soal tentang penyebab terjadinya peristiwa Proklamasi, 4) Mengerjakan latihan soal tentang 5 informasi penting dalam peristiwa Proklamasi, dan 5) Memperesntasikan hasil diskusi tentang faktor penyebab dan 5 informasi penting dalam peristiwa Proklamasi.

Pembelajaran S-TPS adalah pembelajaran yang melibatkan siswa untuk berfikir sendiri terlebih dahulu, kemudian berfikir bersama dengan pasangannya, dan hasil disampaikan kepada seluruh siswa di kelas. Desain pembelajaran S-TPS akan dilaksanakan pada Tema 7 Peristiwa dalam Kehidupan, Subtema 2 Peristiwa Kebangsaan Seputar Proklamasi Kemerdekaan Pembelajaran ke 1. Pembelajaran S-TPS terdiri dari 3 mata pelajaran yaitu Bahasa Indonesia dengan KD 3.5 dan 4.5, IPA dengan KD 3.7 dan 4.7, sedangkan IPS dengan KD 3.4 dan 4.4 melalui langkah-langkah: 1) Menyimak bacaan Peristiwa Proklamasi Kemerdekaan, 2) Menanya tentang Peristiwa Proklamasi Kemerdekaan, 3) Berpikir (Think) untuk mengidentifikasi faktor penyebab dan 5 informasi penting dari peristiwa Proklamasi, 4) Berdiskusi dengan pasangan (Pairs) tentang faktor penyebab dan 5 informasi penting dari peristiwa Proklamasi, 5) Mengumpulkan dan mengolah informasi terkait faktor penyebab dan 5 informasi penting dari peristiwa Proklamasi, 6) Melaporkan hasil diskusi (Sharing) terkait faktor penyebab dan 5 informasi penting dari peristiwa Proklamasi, 7) Menarik kesimpulan tentang Peristiwa Proklamasi Kemerdekaan dengan peta konsep.

Pembelajaran konvensional adalah model pembelajaran klasikal yang berpusat pada guru, sehingga siswa cenderung pasif dan kegiatan pembelajaran hanya mengajarkan konsep bukan kompetensi. 
Pembelajaran konvensional di Tema 7 Subtema 2 Pembelajaran 1 untuk mata pelajaran Bahasa Indonesia dengan KD 3.5 dan 4.5, IPA dengan KD 3.7 dan 4.7, sedangkan IPS dengan KD 3.4 dan 4.4 melalui langkahlangkah: 1) Menyimak bacaan Peristiwa Proklamasi Kemerdekaan dengan ceramah, 2) Bertanya jawab tentang Peristiwa Proklamasi Kemerdekaan, 3) Mengerjakan soal latihan terkait faktor penyebab dan 5 informasi penting dari peristiwa Proklamasi yang dikerjakan secara individu, 4) Membahas soal yang dikerjakan terkait faktor penyebab dan 5 informasi penting dari peristiwa Proklamasi, 5) Mengkonfirmasi hal-hal yang belum diketahui siswa seperti peristiwa Rengasdengklok dan 6) Menyimpulkan inti pembelajaran tentang Peristiwa Proklamasi Kemerdekaan. Kerangka berpikir tentang pengaruh pembelajaran S-TPS terhadap minat belajar siswa kelas 5 SD secara rinci disajikan melalui gambar 1 sebagai berikut.

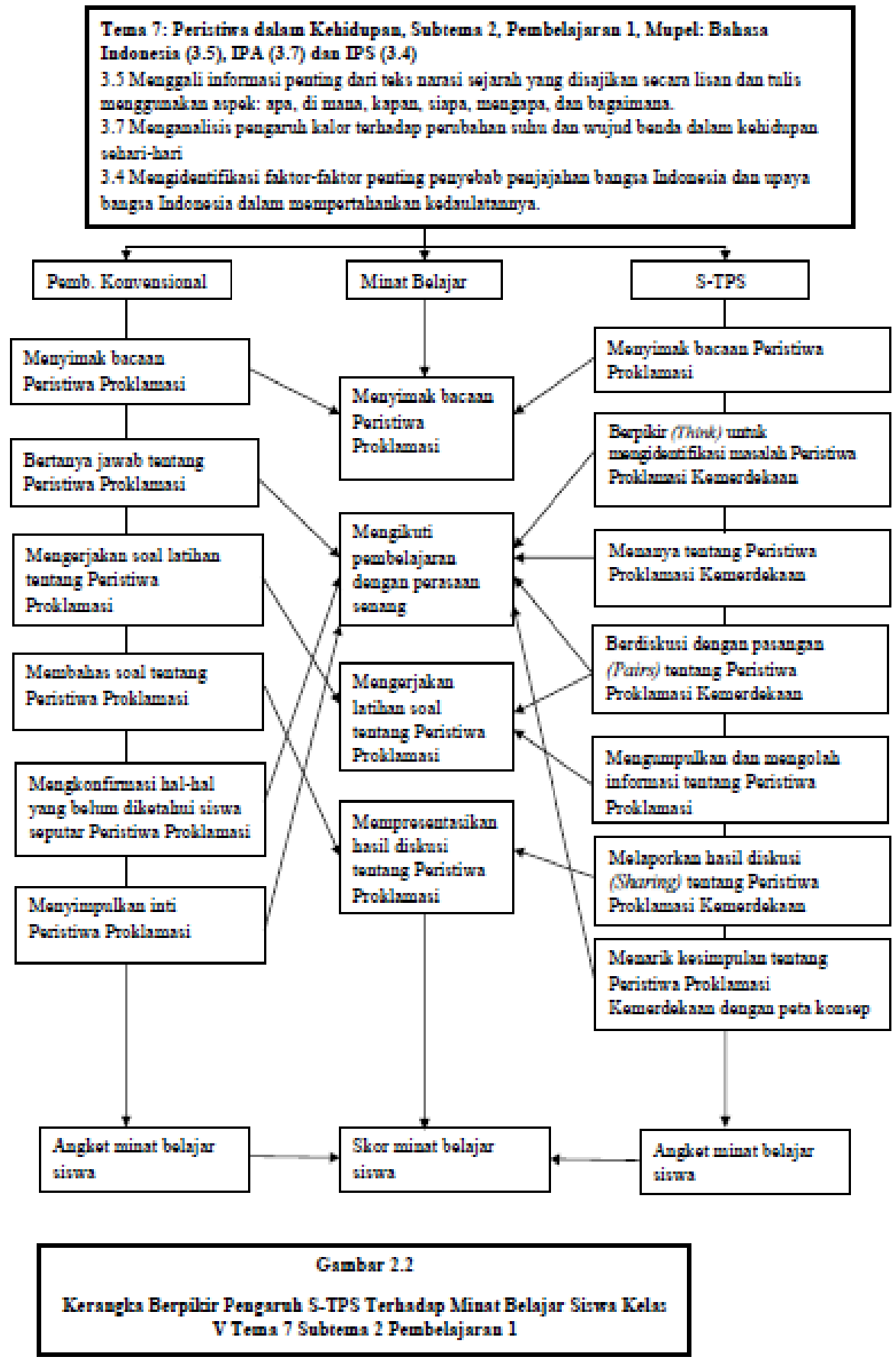

Gambar 1. Kerangka Berpikir Pengaruh Pembelajaran S-TPS Terhadap Minat Belajar Siswa Kelas 5 SD 


\section{Metode}

Jenis penelitian ini adalah penelitian eksperimen dengan menggunakan quasi experimen research. Desain yang digunakan adalah Nonequivalent Control Group Design. Tujuan dari penelitian eksperimen kuasi ini adalah untuk menyelidiki hubungan sebab dan akibat dengan cara memberi perlakuan tertentu pada kelas eksperimen dan menyediankan kelas kontrol sebagai perbandingan. Desain eksperimen penelitian ini secara rinci disajikan dalam tabel 1 sebagai berikut.

Tabel 1. Desain Eksperimen

\begin{tabular}{cll}
\hline 01 & $X$ & 02 \\
\hline 03 & & 04 \\
\hline
\end{tabular}

Keterangan:

X : Perlakuan menggunakan S-TPS

01 : Pengukuran kemampuan awal kelompok eksperimen

02 : Pengukuran kemampuan akhir kelompok eksperimen

03 : Pengukuran kemampuan awal kelompok kontrol

04 : Pengukuran kemampuan akhir kelompok kontrol

Penelitian ini dilakukan di SD Negeri Cebongan 02 Salatiga yang terletak di Jalan Soekarno Hatta No. 101, Kecamatan Argomulyo, Kota Salatiga. Penelitian ini terdapat 2 variabel, yaitu variabel bebas dan variabel terikat. Variabel bebas adalah pendekatan saintifik dan model think pair share, sedangkan variabel terikat adalah minat belajar siswa.

Populasi dalam penelitian ini adalah seluruh siswa SD Negeri Cebongan 02 Salatiga sejumlah 228 siswa. Sampel dalam penelitian ini adalah siswa kelas 5A SDN Cebongan 02 sebanyak 22 siswa, dan siswa kelas 5B SDN Cebongan 02 sebanyak 24 siswa. Teknik pengambilan sampel adalah Purposive Stratified Quota Sampling, artinya sampel diambil dengan menentukan lokasi terlebih dahulu yaitu SD Negeri Cebongan 02 Salatiga Kecamatan Argomulyo, lalu menetapkan kelas eksperimen dengan jumlah siswa 24 dan kelas kontrol dengan jumlah siswa 21. Instrumen pengumpulan data yang digunakan adalah angket minat belajar siswa sebanyak 20 butir pernyataan yang telah di uji validitasnya oleh pakar minat belajar. Teknik analisis data yang digunakan dalam penelitian ini adalah uji t (Independent Sample t-Test).

\section{Hasil dan Pembahasan}

Teknik analisis data dengan uji independent sample t-test digunakan untuk menguji hipotesis dengan kriteria sebagai berikut.

$\mathrm{H}_{\mathrm{o}} \quad$ : Tidak terdapat pengaruh pembelajaran saintifik TPS terhadap minat belajar siswa kelas 5 Tema 7 Subtema 2 Pembelajaran 1 di SD Negeri Cebongan 02 Salatiga semester 2 tahun pelajaran $2018 / 2019$.

$\mathrm{H}_{\mathrm{a}} \quad$ : Terdapat pengaruh pembelajaran saintifik TPS terhadap minat belajar siswa kelas 5 Tema 7 Subtema 2 Pembelajaran 1 di SD Negeri Cebongan 02 Salatiga semester 2 tahun pelajaran $2018 / 2019$.

Uji normalitas digunakan untuk mengetahui apakah data pretest kelas eksperimen dan kelas kontrol berdistribusi normal atau tidak. Pengujian normalitas data menggunakan bantuan uji ShapiroWilk jika jumlah responden kurang dari 50, dengan acuan sebagai berikut 1) Jika nilai signifikansi $<0,05$ maka data tidak berdistribusi normal 2) Sedangkan jika nilai signifikansi $>0,05$, maka data berdistribusi normal. Hasil uji normalitas kelas eksperimen dan kelas kontrol disajikan dalam tabel 2 sebagai berikut.

Tabel 2. Hasil uji Normalitas Kelas Eksperimen dan Kelas Kontrol

\begin{tabular}{lccc}
\hline & \multicolumn{3}{c}{ Shapiro-Wilk } \\
\cline { 2 - 5 } & Statistic & Df & Sig. \\
\hline $\begin{array}{l}\text { Skor minat belajar } \\
\text { kelas eksperimen }\end{array}$ & .948 & 24 & .251 \\
\hline $\begin{array}{l}\text { Skor minat belajar } \\
\text { kelas kontrol }\end{array}$ & .927 & 22 & .106 \\
\hline
\end{tabular}

Berdasarkan tabel 2 hasil uji normalitas kelas eksperimen diperoleh signifikansi sebesar 0,251 atau lebih besar dari 0,05 (0,251 > 0,05), sedangkan hasil uji normalitas kelas kontrol diperoleh signifikansi 
sebesar 0,106 atau lebih besar dari 0,05 $(0,106>0,05)$, maka dapat disimpulkan skor minat belajar pada kelas eksperimen dan kelas kontrol berdistribusi normal.

Selanjutnya jika data pretest kelas eksperimen dan kelas kontrol berdistribusi normal, maka tahap berikutnya adalah dilakukan uji homogenitas. Uji homogenitas dilakukan untuk mengetahui apakah data pretest kelas eksperimen dan kelas kontrol memiliki varian yang sama atau homogen. Acuan yang digunakan dalam uji homogenitas adalah 1) Jika nilai signifikansi $>0,05$, maka data memiliki varian yang sama homogen 2) Jika nilai signifikansi $<0,05$, maka data memiliki varian yang tidak sama atau heterogen. Hasil uji homogenitas kelas eksperimen dan kelas kontrol disajikan dalam tabel 3 sebagai berikut.

Tabel 3. Hasil uji homogenitas kelas eksperimen dan kelas kontrol

\begin{tabular}{cccc}
\hline Levene Statistic & df1 & df2 & Sig. \\
\hline .078 & 1 & 44 & .781 \\
\hline
\end{tabular}

Berdasarkan tabel 3 hasil uji homogenitas kelas eksperimen dan kelas kontrol diperoleh nilai signifikansi sebesar 0,781 atau lebih besar dari $0,05(0,781>0,05)$, leveane statistic sebesar 0,078, maka dapat disimpulkan data kelas eksperimen dan kelas kontrol memiliki varian yang sama atau homogen. Dari paparan di atas maka dapat disimpulkan uji prasyarat dengan menggunakan uji normalitas dan uji homogenitas telah terpenuhi. Selanjutnya uji hipotesis dilakukan dengan menggunakan uji t (independent sample t-test).

Teknik analisis data dalam penelitian ini adalah uji independent sample t-test, dengan melakukan pengujian data posttest kelas eksperimen menggunakan pembelajaran S-TPS terhadap data posttest kelas kontrol menggunakan pembelajaran konvensional. Acuan pengambilan keputusan adalah 1) Jika signifikansi (2-tailed) < 0,05, maka $\mathrm{H}_{\mathrm{o}}$ ditolak dan $\mathrm{H}_{\mathrm{a}}$ diterima, 2) Jika signifikansi (2-tailed) $>0,05$, maka $\mathrm{H}_{\mathrm{o}}$ diterima dan $\mathrm{H}_{\mathrm{a}}$ ditolak. Uji independent sample t-test dilakukan dengan bantuan SPSS versi 20. Hasil uji independent sample t-test disajikan dalam tabel 4 sebagai berikut.

Tabel 4. Hasil uji independent sample t-test

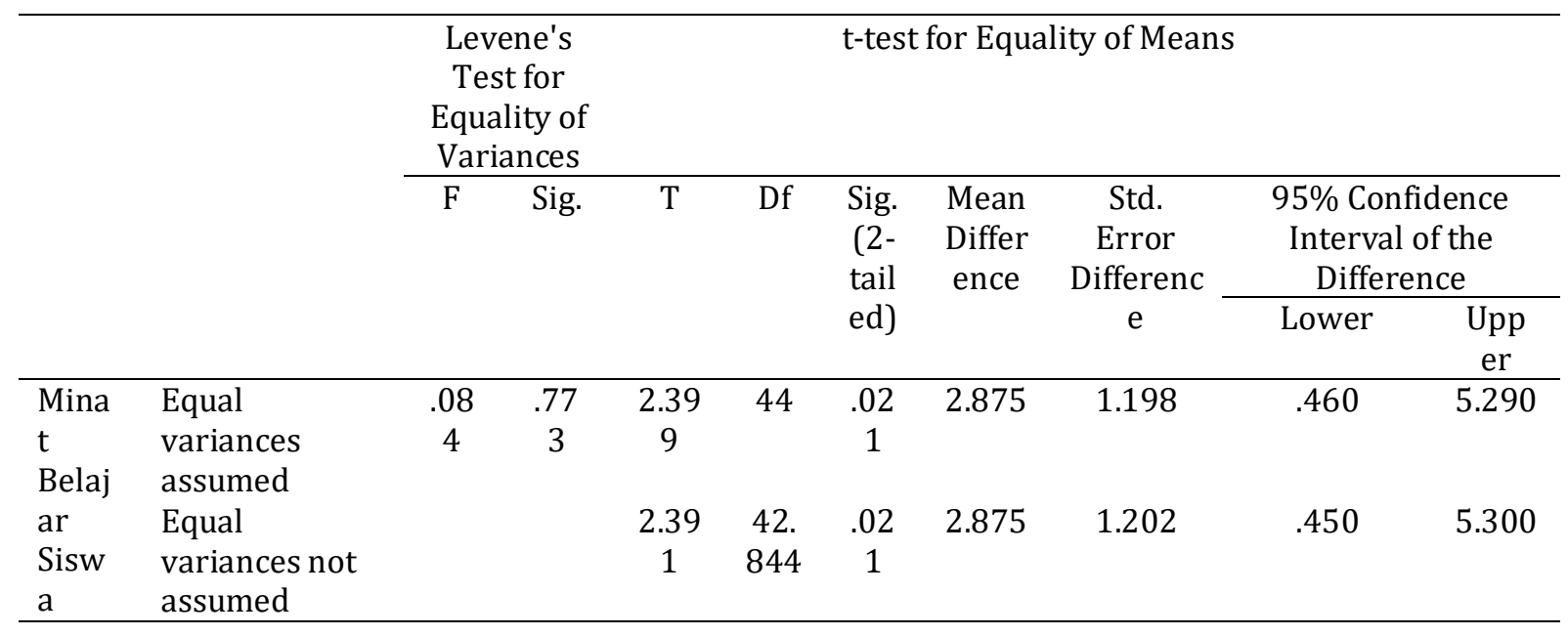

Berdasarkan tabel 4 hasil uji independent sample t-test diketahui nilai t sebesar 2,399 > 2,067 ( $\mathrm{t}$ tabel) dan nilai signifikansi (2-tailed) 0,021 $<0,05$, maka dapat disimpulkan $\mathrm{H}_{0}$ ditolak dan $\mathrm{H}_{\mathrm{a}}$ diterima.

Perbedaan rata-rata skor posttest kelas eksperimen dan kelas kontrol disajikan dalam tabel 5 sebagai berikut.

Tabel 5. Group Statistic Posttest Kelas Eksperimen dan Kelas Kontrol Group Statistics

\begin{tabular}{clcccc}
\hline \multicolumn{2}{c}{ Kelas } & N & Mean & Std. Deviation & $\begin{array}{c}\text { Std. Error } \\
\text { Mean }\end{array}$ \\
\hline $\begin{array}{c}\text { Minat } \\
\text { Belajar } \\
\text { Siswa }\end{array}$ & $\begin{array}{l}\text { Post-Test Kelas } \\
\text { Eksperimen (S- } \\
\text { TPS) }\end{array}$ & 24 & 75.38 & 3.910 & .798 \\
\cline { 2 - 6 } & Post-Test Kelas & 22 & 72.50 & 4.217 & .899 \\
\hline
\end{tabular}




\section{Kontrol \\ (Konvensional)}

Berdasarkan tabel 5 diperoleh rata-rata posttest minat belajar kelas eksperimen sebesar 75,38 sedangkan rata-rata posttest minat belajar kelas kontrol sebesar 72,5. Perbedaan rata-rata skor minat belajar antara kelas eksperimen dan kelas kontrol adalah 2,88. Maka dapat disimpulkan bahwa terdapat perbedaan rata-rata minat belajar antara kelas eksperimen dengan kelas kontrol, rata-rata minat belajar kelas eksperimen dengan menggunakan model S-TPS lebih tinggi daripada kelas kontrol dengan menggunakan model konvensional.

Pembelajaran S-TPS pada siswa kelas 5B SD Negeri Cebongan 02 Salatiga sebagai kelas eksperimen menunjukan minat belajar yang lebih tinggi dibandingkan dengan pembelajaran konvensoinal pada siswa kelas 5A SD Negeri Cebongan 02 Salatiga sebagai kelas kontrol. Klasifikasi skor minat belajar kelas eksperimen dan kelas kontrol disajikan dalam tabel 6 sebagai berikut.

Tabel 6. Klasifikasi Skor Minat Belajar Kelas Eksperimen dan Kelas Kontrol

\begin{tabular}{clcccc}
\hline \multirow{2}{*}{$\begin{array}{c}\text { Skor Peserta } \\
\text { didik }\end{array}$} & Kategori Minat & Frekuensi & $\begin{array}{c}\text { Persentase } \\
(\%)\end{array}$ & Frekuensi & $\begin{array}{c}\text { Persentase } \\
(\%)\end{array}$ \\
\cline { 3 - 5 } & & 11 & 45,8 & 4 & 18,2 \\
$77-80$ & Sangat Berminat & 8 & 33,3 & 8 & 36,4 \\
$73-76$ & Berminat & 4 & 16,7 & 8 & 36,4 \\
$69-72$ & Kurang Berminat & 1 & 4,2 & 2 & 9,1 \\
$65-68$ & Tidak Berminat & 24 & 100 & 22 & 100 \\
& Jumlah & & & \\
\hline
\end{tabular}

Berdasarkan tabel 6 diketahui bahwa pada kelas eksperimen sebanyak 11 siswa termasuk dalam kategori sangat berminat dengan persentase 45,8\%, 8 siswa termasuk dalam kategori berminat dengan persentase 33,3\%, 4 siswa termasuk dalam kategori kurang berminat dengan persentase $16,7 \%$ dan 1 siswa termasuk dalam kategori tidak berminat. Sedangkan pada kelas kontrol sebanyak 4 siswa termasuk dalam kategori sangat berminat dengan persentase 18,2\%, 8 siswa termasuk dalam kategori berminat dengan persentase $36,4 \%$, 8 siswa termasuk dalam kategori kurang berminat dengan persentase $36,4 \%$ dan 2 siswa termasuk dalam kategori tidak berminat dengan persentase 9,1\%.

Hasil penelitian sebelumnya yang mendukung penelitian ini dilakukan oleh Nanang Harianto (2012) menunjukkan hasil signifikansi $0,045<0,05$, dan rata-rata skor minat belajar kelas eksperimen lebih tinggi daripada kelas kontrol yaitu $89,9730>86,4516$, perbedaan rata-rata skor minat belajar 3,52136. Maka dapat disimpulkan penggunaan model Think Pair Share berpengaruh terhadap minat belajar siswa. Penelitian lain yang sejalan dilakukan oleh Annisa Cynthia Yanmi (2016) melakukan penelitian tentang Efektivitas Pembelajaran Kooperatif Tipe TPS dan Pemanfaatan Media Gambar Dalam Peningkatan Minat Belajar dan Hasil Belajar Kognitif IPA Pada Siswa Kelas 4 SD Gugus Abiyoso. Hasil uji Mann-Whitney U-Test menunjukkan signifikansi 0,000 <0,05, maka dapat disimpulkan model Kooperatif Tipe TPS efektif meningkatkan minat belajar siswa.

Penelitian lain yang sejalan juga dilakukan oleh Yani Purbaningrum (2012) melakukan penelitian tentang Upaya Peningkatan Minat dan Hasil Belajar Siswa Melalui Penerapan Think Pair Share (TPS) pada Mata Pelajaran Ilmu Pengetahuan Alam (IPA) Kelas V SD Negeri Rowosari Semester II Tahun Pelajaran 2013/2014, menunjukkan hasil signifikansi $0,002<0,05$, perbedaan rata-rata hasil belajar kelas eksperimen 86,27 sedangkan hasil belajar kelas kontrol 81,79. Maka dapat disimpulkan model pembelajaran Think Pair Share terbukti dapat meningkatkan minat dan hasil belajar siswa di kelas 5 SD.

Hasil analisis skor minat belajar siswa kelas eksperimen dengan pemberian perlakuan S-TPS dan skor minat belajar siswa kelas kontrol dengan pemberian perlakuan pembelajaran konvensional menunjukkan hasil yang berbeda. Skor rata-rata pretest dan posttest kelas eksperimen lebih tinggi dibandingkan dengan kelas kontrol. Maka dari itu pembelajaran S-TPS lebih berpengaruh terhadap minat belajar siswa.

Minat belajar siswa kelas eksperimen lebih tinggi dikarenakan pada saat pembelajaran dengan menggunakan S-TPS siswa lebih antusias mengikuti setiap tahapan dalam pembelajaran. Ketika siswa menerima materi peristiwa Proklamasi, semua siswa menyimak materi yang diberikan guru dengan baik tanpa ada yang ramai sendiri. Setelah siswa menerima materi dari guru, masing-masing siswa berpikir untuk mengidentifikasi masalah tentang peristiwa Proklamasi Kemerdekaan. Ketika guru memberikan kesempatan untuk bertanya tentang peristiwa Proklamasi ada 5 siswa yang bertanya. Minat belajar siswa 
mulai nampak ketika siswa berdiskusi dengan pasangan atau teman sebangku. Siswa bekerja sama mengungkapkan pendapat untuk memecahkan masalah, mengumpulkan informasi dari buku sejarah Indonesia dan mengolah informasi yang didapat. Setelah berdiskusi dengan pasangan, siswa mempresentasikan hasil diskusi di depan kelas dengan percaya diri dan penuh semangat. Ketika kelompok selesai mempresentasikan hasil diskusi, siswa lain menanggapi dan menambahkan jawaban yang belum diutarakan.

Pembelajaran dengan S-TPS membuat siswa berperan aktif dalam kegiatan pembelajaran. Siswa tidak hanya duduk diam mendengarkan penjelasan dari guru, namun siswa mencari tahu pengetahuan yang ingin mereka dapatkan. Siswa bekerjasama mengumpulkan dan mengolah informasi daris sumber buku lain, dan membagikan informasi yang sudah didapat kepada semua teman di kelas. Dari kegiatan tersebut siswa diajarka untuk saling bekerja sama dengan kelompok dan bertanggung jawab menyelesaikan seluruh tugas yang diberikan guru. Minat belajar siswa pada kelas kontrol dengan pembelajaran konvensional cenderung rendah. Hal ini dikarenakan pembelajaran lebih berpusat pada guru. Ketika siswa diberi kesempatan untuk bertanya maupun mengungkapkan pendapatnya, namun hanya 2 anak yang berani bertanya, dan hanya 5 anak yang berani mengungkapkan pendapatnya. Kegiatan pembelajaran juga tidak melibatkan interaksi siswa secara menyeluruh, sehingga membuat siswa mudah merasa bosan ketika belajar.

\section{Simpulan dan Saran}

Terdapat pengaruh pembelajaran saintifik TPS terhadap minat belajar tematik Tema 7 Subtema 2 Pembelajaran 1 siswa kelas 5 SD Negeri Cebongan 02 Salatiga tahun pelajaran 2018/2019. Sehingga pendekatan saintifik dan model think pair share memiliki pengaruh untuk meningkatkan minat belajar dalam pembelajaran tematik dikelas 5 SD Negeri Cebongan 02 Salatiga. Hal ini diperkuat dengan hasil uji t (indipendent sample t-test), antara kelas eksperimen dan kelas kontrol menunjukkan signifikansi (2tailed) 0,021 $<0,05$ dan hasil t-hitung 2,399 > 2,067 t-tabel, maka Ha diterima. Sedangkan rata-rata posttest skor minat belajar kelas eksperimen 75.38 dan kelas kontrol 72.50. Perbedaan rata-rata posttest skor minat belajar adalah 2,88.

Saran yang dapat diajukan untuk pengembangan proses pembelajara adalah guru sebagai salah satu komponen penting dalam pendidikan diharapkan dapat menggunakan pendekatan saintifik dan model think pair share sebagai alternatf untuk meningkatkan minat belajar siswa. Namun dalam penggunaan pendekatan saintifik dan model think pair share harus disesuaikan dengan karakteristik dan kebutuhan siswa ketika pembelajaran berlangsung.

\section{Daftar Rujukan}

Abdul Majid dan Chaerul Rochman. (2014). Pendekatan Ilmiah dalam Implementasi Kuirikulum 2013. Bandung: PT Remaja Rosdakarya.

Akbar, R., \& Hawadi. (2004). Akselerasi: A-Z Program Percepatan Belajar dan Anak Berbakat Intelektual. Jakarta: Grasindo.

Djaali. (2012). Psikologi Pendidikan. Jakarta: Bumi Aksara.

Djamarah, S. B. dan Z. A. (2010). Strategi Belajar Mengajar. Jakarta: PT Rineka Cipta.

Djiwandono, S. E. P. (2002). Psikologi Pendidikan. Jakarta: Grasindo.

Kemendikbud. (2003). Undang-Undang Nomor 20 Tahun 2003 tentang Sistem Pendidikan Nasional (SISDIKNAS). Jakarta: Kementrian Pendidikan dan Kebudayaan.

Kurniasih, Imas, dkk. (2014). Sukses Mengimplementasikan Kurikulum 2014. Surabaya: PT. Kata Pena.

Molstad, C. E., \& Karseth, B. (2016). National Curricula in Norway and Finland: The Role of Learning Outcomes. The Role of Learning Outcomes. European Educational Research Journal, 15(3), 329-344.

Mulyasa, H. E. 2014. (2014). Pengembangan dan Implementasi Kurikulum 2013. Bandung: Rosdakarya.

Musanna, A. (2017). Indigenisasi Pendidikan: Rasionalitas Revitalisasi Praksis Pendidikan Ki Hadjar Dewantara. Jurnal Pendidikan Dan Kebudayaan, 2(1), 117-133.

Nemeth, J., \& Long, J. G. (2012). Assessing Learning Outcomes in U.S. Planning Studio Courses. Journal of Planning Education and Research. Journal of Planning Education and Research, 32(4), 476-490.

Nurkholis. (2013). Pendidikan dalam upaya memajukan teknologi. Jurnal Kependidikan, 1(1), 24-44.

Slameto. (2013). Belajar dan Faktor-faktor yang Mempengaruhinya. Jakarta: Rineka Cipta.

Trianto. (2013). Mendesain Model Pembelajaran Inovatif, Progresif, Konsep, Landasan, dan Implementasinya Pada Kurikulum Tingkat Satuan Pendidikan (KTSP. Jakarta: Kencana Prenada Media Group.

Wardani, E. P., Mardiyana, M., \& Subanti, S. (2016). Analisis Miskonsepsi Siswa Pada Materi Pokok 
Lingkaran Ditinjau Dari Kesiapan Belajar Dan Gaya Berpikir Siswa Kelas Xi Ipa Sma N 3 Surakarta Tahun Ajaran 2013/2014. Jurnal Pembelajaran Matematika, 4(3), 328-340.

Young, M. E., Klemz, B. R., \& Murphy, J. W. (2003). Enhancing Learning Outcomes: The Effects of Instructional Technology, Learning Style, Instructional Methods and Student Behavior. Journal of Marketing Education, 25, 130. 